\section{PCR-Based Assay to Determine Nuclear Matrix Association}

BioTechniques 22:826-828 (May 1997)

The interactions of chromatin with the proteinaceous nuclear matrix have come under intense study. Somatic chromatin is organized into approximately 60-kb loops, which are attached at their base to the nuclear matrix at matrix attachment regions (MARs) (13). It has been suggested that transcribed genes are associated with the nuclear matrix (Reference 11 and references therein), and MARs have been co-localized to various regulatory elements $(1,5)$. No clear consensus sequence has been established for MARs, and it is apparent that many MAR sequences are active in a context-dependent manner (12). For example, a constitutive MAR has been identified in the vicinity of the mouse $\beta$-globin gene that is independent of the cell's differ- entiative state (6), and chicken histone genes have been shown to retain association with the nuclear matrix throughout the cell cycle (3). In contrast, several avian nuclear matrix proteins have been identified that bind tightly to an avian $\beta$-globin MAR in a tissue-specific manner (2), and a significant fraction of nonstructural nuclear matrix proteins have been shown to be cell-specific (4). This variation may reflect the multiple classes of MARs that have recently been proposed (8). It is clear that many more individual MARs must be identified before any precise conclusions on the nature of MARs can be drawn. We report a rapid polymerase chain reaction (PCR)-based assay to identify MARs in nuclear matrix-bound and nuclear matrix-independent fractionated chromatin that will facilitate this task. All that is required to begin to map sites of nuclear matrix interaction is a restriction map and PCR primer sets that are within a single small region of each of a few selected fragments.

Cultured cells were collected and snap-frozen in $250-\mu \mathrm{L}$ aliquots of approximately $15 \times 10^{6}$ cells in frozen storage buffer (FSB) composed of 50 $\mathrm{mM}$ HEPES buffer containing $10 \mathrm{mM}$ $\mathrm{NaCl}, \mathrm{pH} 7.5,5 \mathrm{mM}$ magnesium acetate plus $25 \%$ glycerol. We have found that cells thus frozen can be stored at $-70^{\circ} \mathrm{C}$ indefinitely without loss of structural integrity. Nuclear halo structures were prepared essentially as described (10). Specifically, cells previously frozen in FSB were rapidly handthawed, brought up to $1 \mathrm{~mL}$ with phosphate-buffered saline (PBS), then centrifuged at $4^{\circ} \mathrm{C}$ for $5 \mathrm{~min}$ at $7500 \times \mathrm{g}$. The cell pellet was washed two more times with PBS and then suspended in nuclei buffer composed of $10 \mathrm{mM}$ Tris$\mathrm{HCl}$ (pH 7.7) buffer containing 100 $\mathrm{mM} \mathrm{NaCl}, 0.3 \mathrm{M}$ sucrose, $3 \mathrm{mM}$ $\mathrm{MgCl}_{2}$ plus $0.5 \%$ Triton ${ }^{\circledR} \mathrm{X}-100$. This was followed by incubation for $15 \mathrm{~min}$ on ice. The resulting nuclei were washed twice with PBS, then suspended in $1 \mathrm{~mL}$ of a halo solution comprised of $10 \mathrm{mM}$ Tris- $\mathrm{HCl}(\mathrm{pH} 7.7)$ buffer containing $10 \mathrm{mM}$ EDTA and $2 \mathrm{M}$

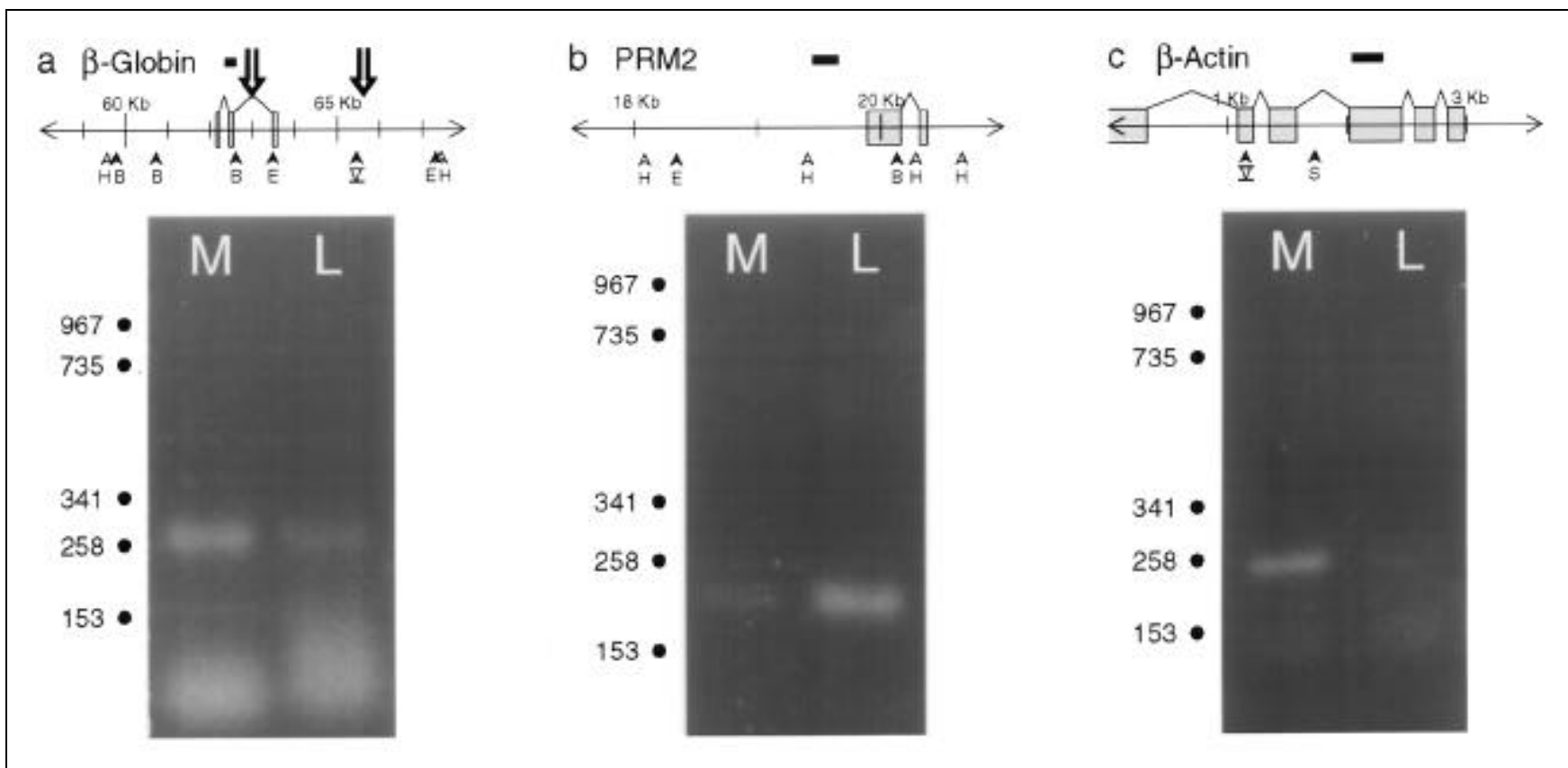

Figure 1. The identification of MARs in several genic domains. The positions of exons of the various genes are shown as gray boxes. The amplicons are represented as thin black boxes above the line, and positions along each sequence are indicated. Note that the human $\beta$-globin amplicon, while actually the largest of the three, appears smaller because of the difference in scaling in Panel a. Restriction endonuclease sites are indicated as open arrowheads for HindIII (H), and closed arrowheads for BamHI (B), EcoRI (E), EcoRV (V) and SacI (S). The approximate positions of two known MARs within the human $\beta$-globin locus are indicated as arrows above the line. The GenBank ${ }^{\circledR}$ accession numbers for the sequences used are indicated below. (a) The $\beta$-globin major gene (locus HUMHBB, multiple accession numbers) lies within a HindIII restriction fragment that contains two known MARs (7). Amplification of equal aliquots of both the pellet (matrix-associated, $[\mathrm{M}]$ ) and the supernatant (matrix-independent, or loop [L]) fractions reveals a nearly threefold greater amount in the matrix-associated fraction. (b) The human protamine 2 (PRM2) gene (Accession No. U15422) is not associated with the somatic nuclear matrix. The PRM2 amplicon is three times more strongly represented in the supernatant (matrix-independent) fraction. (c) The human $\beta$-actin gene (Accession No. M10277) lies near a region that is very strongly associated with the HeLa nuclear matrix ( $>5$-fold more in the matrix-associated fraction). 
$\mathrm{NaCl}$. The sample was then incubated on ice for $15 \mathrm{~min}$, then centrifuged at $4^{\circ} \mathrm{C}$ for $10 \mathrm{~min}$ at $12000 \times \mathrm{g}$. The supernatant was removed, and the resulting halo structures were suspended in 100 $\mu \mathrm{L}$ of $10 \mathrm{mM}$ Tris- $\mathrm{HCl}(\mathrm{pH} 7.5)$ containing $50 \mathrm{mM} \mathrm{NaCl}, 10 \mathrm{mM} \mathrm{MgCl}{ }_{2}$ and $1 \mathrm{mM}$ dithiothreitol (DTT), then digested with HindIII (Amersham, Cleveland, $\mathrm{OH}, \mathrm{USA}$ ) for $4 \mathrm{~h}$ at $37^{\circ} \mathrm{C}$. An equal volume of $4 \mathrm{M} \mathrm{NaCl}$ was added, and the sample was incubated for an additional $15 \mathrm{~min}$ at $37^{\circ} \mathrm{C}$; it was then centrifuged at $4^{\circ} \mathrm{C}$ for $30 \mathrm{~min}$ at $12000 \times g$. The supernatant, which contained the matrix-independent fraction, was transferred to a new tube. The pellet, which contained the matrix-bound fraction, was suspended in $200 \mu \mathrm{L}$ of TE buffer (10 mM Tris-HCl, $\mathrm{pH} 8.0,1$ mM EDTA). DNA was purified from both fractions using the Prep-A-Gene ${ }^{\circledR}$ Matrix (Bio-Rad, Hercules, CA, USA) then subjected to PCR amplification (primer sequences and PCR conditions are available at the Internet address http://compbio.med.wayne.edu/). PCR was maintained within the linear range; for example, increasing the concentration of template or the number of cycles proportionally increased the signal.

This protocol was carried out as described above using cultured $\mathrm{HeLa}$ cells. Equal amounts of the nuclear matrix-bound (i.e., pellet) and the nuclear matrix-free (i.e., supernatant) fractions were then used for amplification with several PCR primer pairs as shown in Figure 1. The PCR primer pair directed to the human $\beta$-globin major gene corresponds to an amplicon spanning exon 2. The HindIII genomic fragment that contains this amplicon contains two known MARs as indicated in Figure 1a (7). PCR amplification of the pellet and supernatant fractions shows that the $\beta$ globin amplicon clearly partitions to the pellet (nuclear matrix-associated) fraction. In contrast, the human male haploid-expressed protamine 2-specific primers show that this amplicon predominantly localizes to the loop (nuclear matrix-independent) fraction (Figure $1 b$ ), in accord with previously reported results $(8,9)$. Similar to the $\beta$ globin gene, the human $\beta$-actin primers amplify a region that is nuclear matrixassociated in HeLa cells (Figure 1c), demarcating a nuclear matrix-binding component near the human $\beta$-actin gene. The position of the MAR cannot be ascertained because the available sequence data for this region does not include any HindIII restriction sites.

The technique described above is a useful method for the identification of MARs in the somatic nucleus and in the male haploid nucleus (8). It is both rapid and accurate, and does not require the use of radioisotopes. Using this technique, we have identified regions at least as large as $16 \mathrm{~kb}$ that contain MARs (8). The use of more frequently cutting restriction enzymes, with several strategically localized primer pairs within that region, has enabled the identification of the segment that contains the nuclear matrix attachment site.

\section{REFERENCES}

1.Boulikas, T. 1994. Transcription factor binding sites in the matrix attachment region (MAR) of the chicken $\alpha$-globin gene. J. Cell. Biochem. 55:512-529.

2.Brotherton, T., D. Zenk, S. Kahanic and J. Reneker. 1991. Avian nuclear matrix proteins bind very tightly to cellular DNA of the $\beta$-globin gene enhancer in a tissue-specific fashion. Biochemistry 30:5845-5850.

3.Dalton, S., H.B. Younghusbad and J.R.E. Wells. 1986. Chicken histone genes retain nuclear matrix attachment throughout the cell cycle. Nucleic Acids Res. 14:6507-6523.

4.Fey, E.G. and S. Penman. 1988. Nuclear matrix proteins reflect the cell type of origin in cultured human cells. Proc. Natl. Acad. Sci. USA 85:121-125.

5.Gasser, S.M. and U.K. Laemmli. 1986. Cohabitation of scaffold binding regions with upstream/enhance elements of three developmentally regulated genes of $D$. melanogaster. Cell 46:521-530.

6.Greenstein, R.J. 1988. Constitutive attachment of murine erythroleukemia cell histonedepleted DNA loops to nuclear scaffolding is found in the $\beta$-major but not the $\alpha 1$-globin gene. DNA 7:601-607.

7.Jarman, A.P. and D.R. Higgs. 1988. Nuclear scaffold attachment sites in the human globin gene complexes. EMBO J. 7:3337-3344.

8.Kramer, J.A. and S.A. Krawetz. 1996. Nuclear matrix interactions within the sperm genome. J. Biol. Chem. 271:11619-11622.

9.Kramer, J.A., G.B. Singh and S.A. Krawetz. 1996. Computer-assisted search for sites of nuclear matrix attachment. Genomics 33:305308.

10.Mirkovitch, J., S.M. Gasser and U.K. Laemmli. 1988. Scaffold attachment of DNA loops in metaphase chromosomes. J. Mol. Biol. 200:101-109.

11.Robinson, S.I., D. Small, R. Idzerda, G.S. McKnight and B. Vogelstein. 1983. The association of transcriptionally active genes with the nuclear matrix of the chicken oviduct. Nu- cleic Acids Res. 11:5113-5130.

12.Schübeler, D., C. Mielke, K. Maass and J. Bode. 1996. Scaffold matrix-attached regions act upon transcription in a context-dependent manner. Biochemistry 35:11160-11169.

13.Vogelstein, B., D.M. Pardoll and D.S. Coffey. 1980. Supercoiled loops and eucaryotic [sic] DNA replication. Cell 22:79-85.

J.K. is supported in part by the Dean's Postdoctoral Recruitment Fellowship and a Lalor Foundation Fellowship. Address correspondence to Stephen A. Krawetz, Department of Obstetrics \& Gynecology, Center for Molecular Medicine and Genetics, Wayne State University School of Medicine, 275 E. Hancock, Detroit, MI 48102, USA. Internet: steve@compbio.med.wayne.edu

Received 5 August 1996; accepted 12 November 1996. Jeffrey A. Kramer and
Stephen A. Krawetz Wayne State University School of Medicine Detroit, MI, USA 